\title{
Analisis Kesulitan Belajar Siswa Pada Pembelajaran Bahasa Indonesia Di Kelas V SDN 12 Singkawang
}

\author{
Nani $^{1}$, Evinna Cinda Hendriana ${ }^{2}$ \\ Pendidikan Guru Sekolah Dasar, STKIP Singkawang, Singkawang, Indonesia \\ nani25031999@gmail.com ${ }^{1}$,evinnacinda@yahoo.com ${ }^{2}$
}

\author{
Keywords : \\ Kesulitan Belajar, Bahasa \\ Indonesia
}

\begin{abstract}
Kesulitan belajar merupakan sebuah permasalahan yang menyebabkan seorang siswa belum dapat mengikuti proses pembelajaran dengan baik dan belum mampu untuk mencapai tujuan pembelajaran yang diharapkan. Empat kompetensi dasar yang harus dimiliki siswa pada pembelajaran bahasa Indonesia tingkat sekolah dasar mencakup aspek: menyimak, berbicara, membaca dan menulis. Penulisan artikel ini bertujuan untuk mengkaji dan menganalisis kesulitan belajar siswa pada pembelajaran Bahasa Indonesia di kelas V SDN 12 Singkawang. Artikel ini merupakan hasil analisis dengan mengkaji literature yang memiliki keterkaitan dengan topik pembahasan. Model yang digunakan adalah studi literatur atau lirature riview. Hasil penelitian ini adalah sebagian besar siswa masih tidak faham ketika guru menyampaikan materi Bahasa Indonesia. Terdapat beberapa faktor yang menyebabkan siswa kesulitan belajar Bahasa Indonesia. Berdasarkan hasil tersebut maka dapat disimpulkan bahwa siswa kelas V SDN 12 Singkawang masih berkesulitan dalam mempelajari pelajaran Bahasa Indonesia.
\end{abstract}

\section{INTRODUCTION}

Fenomena kesulitan belajar seorang siswa biasanya tampak jelas dari menurunnya kinerja akademik atau belajarnya yang dilihat dari tidak tercapainya hasil belajar yang sesuai dengan ketentuan yang telah ditetapkan. Namun, kesulitan belajar juga dapat dibuktikan dengan munculnya kelainan prilaku siswa seperti suka membuat gaduh di dalam kelas, mengusik teman, berkelahi, sering tidak masuk sekolah dan sering bolos dari sekolah. Pada hakikatnya kesulitan belajar merupakan sebuah permasalahan yang menyebabkan seorang siswa tidak dapat mengikuti proses pembelajaran dengan baik seperti siswa lain pada umumnya yang menyebabkan siswa tersebut tidak mampu untuk mencapai tujuan belajar yang diharapkan. Dalam kurikulum 2013 pelajaran bahasa Indonesia diintegrasikan dengan pelajaran lainnya. Sasarannya adalah agar siswa terampil dalam menggunakan bahasa (Subana dalam Mardhatillah, 2016:15) . Empat kompetensi dasar yang harus dimiliki siswa pada pembelajaran bahasa Indonesia tingkat sekolah dasar mencakup : aspek menyimak, berbicara, membaca dan menulis. Dalam kurikulum 2013 semua aspek tersebut terintegrasi ke dalam KI (Kompetensi Inti) dan KD (Kompetensi Dasar) pada masing-masing sub tema. 
Kesulitan dalam pembelajaran Bahasa Indonesia yang pertama berupa kesulitan menyimak. Kesulitan menyimak tersebut menjadi hambatan masuknya informasi kepada siswa. Hambatan tersebut dapat berupa salah persepsi atau tidak utuhnya informasi yang sampai kepada siswa. Hal ini jelas akan memberikan dampak negatif terhadap perkembangan kecerdasan dan prestasi siswa tersebut di sekolah. Sejalan dengan hal tersebut Saddhono (2012: 4) mengatakan bahwa "kemampuan menyimak adalah kemampuan berbahasa pertama yang dimilki oleh manusia dalam pemerolehan bahasa". Bertolak dari pendapat tersebut, bisa dikatakan bahwa kemampuan menyimak merupakan modal awal seseorang untuk berkomunikasi.

Berbicara pun menjadi kesulitan siswa dalam pembelajaran Bahasa Indonesia. Berdasarkan pengamatan guru di kelas menunjukkan bahwa dalam kegiatan pembelajaran kemampuan berbicara , siswa masih banyak mengalami kesulitan dalam mempraktikkannya. Selama ini siswa sulit untuk berbicara di depan umum karena rasa kurang percaya diri siswa untuk berekspresi. Rasa kecemasan siswa terhadap penampilannya dalam berbicara membuat mereka enggan untuk melakukannya. Rasa kecemasan akan kesalahan berbahasa seperti penggunaan tata bahasa, pemilihan kosakata, pelafalan, tekanan atau intonasi dapat menghalangi siswa untuk berbicara, sehingga siswa tidak dapat menunjukkan kemampuan berbicaranya dengan maksimal. Permasalahan yang sangat fatal adalah adanya pengaruh penggunaan bahasa ibu dan bahasa daerah yang sering mereka gunakan sehari-hari dalam berkomunikasi. Sehingga menyebabkan siswa kesulitan untuk menggunakan bahasa Indonesia dengan baik dan benar. Secara bersamaan, muncul permasalahan lain yang dapat menghambat kemampuan siswa dalam berbicara, yaitu kesalahan konsep dalam pembelajaran bahasa Indonesia. Siswa seringkali tidak membiasakan diri untuk berlatih menggunakan bahasa Indonesia dalam berkomunikasi sehingga menyebabkan siswa kesulitan untuk meningkatkan kemampuan berbicara mereka. Hal ini juga akan mempengaruhi kepribadian siswa karena mereka kesulitan dalam menyampaian ide, gagasan, dan pikiran mereka saat proses pembelajaran berlangsung.

Selain berbicara, membaca pun tidak kalah penting dengan halnya berbicara. Kemampuan membaca yang benar menjadi modal dasar dan penentu utama keberhasilan dalam berbagai mata pelajaran. Begitupun sebaliknya kegagalan dalam penguasaan kemampuan belajar membaca akan menjadi penghambat atau bahkan akan menjadi salah satu sumber kegagalan dalam studi siswa di sekolah. Banyak siswa yang belum memahami konsep-konsep dalam pelajaran Bahasa Indonesia sehingga siswa kesulitan untuk mengembangkan pemahamannya terhadap materi. Misalnya saja siswa kesulitan dalam memahami teks, kesulitan dalam menulis pantun/puisi dengan benar, kesulitan dalam hal berbicara di depan kelas untuk menceritakan kembali apa yang telah dibaca dengan menggunakan bahasa yang diolahnya sendiri.

Selanjutnya, berdasarkan wawancara saya kepada salah satu guru yang mengajar Bahasa Indonesia, salah satu kesulitan belajar bahasa Indonesia menurut siswa yaitu karena bahasa Indonesia cenderung banyak menulis. Menulis merupakan kegiatan penting dalam proses pembelajaran setelah membaca, sesorang menulis pasti mempunyai suatu tujuan yang ingin disampaikan. Menulis adalah menurunkan atau melukiskan lambang-lambang grafik yang menggambarkan suatu bahasa yang dipahami oleh sesorang, sehingga orangorang lain dapat membaca lambing-lambang grafik tersebut kalau mereka memahami bahasa dan gambaran grafik itu. Lado (Tarigan 2013 : 22). Siswa mengalami kesulitan dari segi penulisan kalimat, siswa belum mampu menulis dengan baik dan benar. Sebagian besar siswa masih belum paham cara menggunakan tanda baca, penulisan huruf capital, dan penggunaan gaya bahasa. Penulisan seringkali menjadi salah satu kesulitan bagi siswa dalam mengimplementasikannya. Setiap siswa mempunyai kemampuan dalam menulis yang sama, namun tidak setiap siswa mempunyai keterampilan menulis yang sama.

Siswa dikatakan mengalami kesulitan belajar Bahasa Indonesia dapat dilihat dari pengamatan guru saat mengajar di kelas, di saat guru memberikan penugasan kepada siswa, dan hasil akhir dari pekerjaan siswa masih rata-rata rendah. Artinya, siswa masih belum mencapai tujuan pelajaran yang diharapkan guru. Guru bahasa Indonesia SD diharapkan dapat memberikan pembelajaran yang 
menarik, inovatif, dan yang mendukung sesuai dengan kebutuhan dan karakteristik siswa di kelas yang akan mengatasi kesulitan belajar pada pembelajaran Bahasa Indonesia. Sejalan dengan Irham dan Wiyani (2014: 254) . Menyatakan bahwa "siswa akan dikatakan mengalami kesulitan belajar apabila intelegensi yang dimilikinya tergolong rata-rata atau normal, akan tetapi menunjukkan adanya kekurangan dalam proses dan hasil belajar seperti prestasi belajar yang diperolehnya rendah.”

Berdasarkan uraian permasalahan di atas, peneliti akan melakukan kegiatan analisis untuk mendeskripsikan, menyelidiki, merincikan kesulitan belajar pada pembelajaran bahasa Indonesia yang dialami oleh siswa di kelas V SDN 12 Singkawang.

\section{METHOD}

Artikel ini menggunakan studi literatur atau literature riview dengan menganalisis beberapa kajian yang berkaitan dengan topik pembahasan yaitu kesulitan belajar, dan bahasa Indonesia. Sumbersumber rujukan yang menjadi pokok bahasan bersumber dari buku, jurnal artikel, prosiding dan yang lainnya. Hal tersebut dimaksudkan untuk meninjau kesulitan belajar siswa pada pembelajaran Bahasa Indonesia di Kelas V SDN 12 Singkawang.

\section{RESULTS AND DISCUSSIONS}

\section{Pembelajaran Bahasa Indonesia di Sekolah Dasar}

Bahasa memiliki peran sentral dalam perkembangan intelektual, sosial dan emosional peserta didik, serta merupakan penunjang keberhasilan dalam mempelajari semua bidang studi. Pembelajaran Bahasa diharapkan membantu peserta didik mengenal dirinya, budayanya dan budaya orang lain, mengemukakan gagasan dan perasaan, partisipasi dalam masyarakat yang menggunakan bahasa tersebut, dan menemukan serta menggunakan kemampuan analisis dan imaginatif yang ada dalam dirinya.

Pembelajaran Bahasa Indonesia diarahkan untuk meningkatkan kemampuan peserta didik untuk berkomunikasi dalam bahasa Indonesia dengan baik dan benar, baik secara lisan maupun secara tulis, serta menumbuhkan apresiasi terhadap hasil karya kesastraan manusia indonesia (Depdiknas , 2007 : 124).

\section{Tujuan Pembelajaran Bahasa Indonesia di Sekolah Dasar} berikut :

Mata pelajaran bahasa Indonesia bertujuan agar peserta didik memiliki kemampuan sebagai

1. Berkomunikasi secara efektif dan efisien sesuai dengan etika yang berlaku, baik secara lisan maupun tulis,

2. Menghargai dan bangga menggunakan bahasa Indonesia sebagai bahasa persatuan dan bahasa negara

3. Memahami bahasa Indonesia dan menggunakannya dengan tepat dan kreatif untuk berbagai tujuan

4. Menggunakan bahasa Indonesia untuk meningkatkan kemampuan intelektual serta kematangan emosional dan sosial

5. Menikmati dan memanfaatkan karya sastra untuk memperluas wawasan, memperhalus budi pekerti serta meningkatkan pengetahuan dan kemampuan berbahasa.

6. Menghargai dan membanggakan sastra indonesia sebagai khazanah budaya dan intelektual manusia Indonesia (Depdiknas, 2007 : 125).

\section{Aspek Pembelajaran Bahasa Indonesia}

1. Menyimak, seperti menyimak berita, petunjuk, pengumuman, perintah, dan bunyi atau suara, bunyi bahasa lagu, kaset, pesan, penjelasan, laporan, ceramah, khotbah, pidato, pembicaraan nara sumber, dialog atau percakapan, pengumuman serta perintah yang disimak dengan memberikan respon secara tepat serta mengapresiasi sastra berupa dongeng, cerita anak-anak, cerita rakyat, cerita binatang, puisi anak, syair lagu, pantun dan menonton drama anak. 
2. Berbicara, seperti mengungkapkan gagasan dan perasaan , menyampaikan sambutan, dialog, pesan, pengalaman, suatu proses, menceritakan diri sendiri, teman, keluarga, masyarakat, benda, tanaman, binatang, gambar tunggal, gambar seri, kegiatan sehari-hari, peristiwa, tokoh, kesukaan/ketidaksukaan, kegemaran, peraturan, tata petunjuk, dan laporan, serta mengapresiasi dan berekspresi sastra melalui kegiatan menuliskan hasil sastra berupa dongeng cerita anakanak, cerita rakyat, cerita binatang, puisi anak, syair lagu, pantun, dan drama anak.

3. Membaca, seperti membaca huruf, suku kata, kata, kalimat, paragraf, berbagai teks bacaan, denah, petunjuk, tata tertib, pengumuman, kamus, ensiklopedi, serta mengapresiasi dan berekspresi, sastra melalui kegiatan membaca hasil sastra berupa dongeng, cerita anak-anak, cerita rakyat, cerita binatang, puisi anak, syair lagu, pantun, dan drama anak.

4. Menulis, seperti menulis karangan naratif dan normatif dengan tulisan rapi dan jelas dengan memperhatikan tujuan dan ragam pembaca, pemakaian ejaan dan tanda baca dan kosa kata yang tepat dengan menggunakan kalimat tunggal dan kalimat majemuk, serta mengapresiasi dan berekspresi sastra melalui kegiatan menulis hasil sastra berupa cerita.

\section{Kesulitan dalam Belajar Bahasa Indonesia}

Perbuatan belajar adalah perbuatan yang sangat kompleks, proses berlangsung dalam otak manusia. Proses belajar pada dasarnya merupakan kegiatan yang bersifat individual untuk memperoleh suatu hasil yang ingin dicapai. Belajar adalah suatu proses perubahan tingkah laku sebagi hasil dari pengalaman (menurut psikolog tingkah laku). Perubahan sebagai hasil dari kegiatan belajar dapat juga berupa penguasaan, penggunaan mengenai sikap, nilai, dan pengetahuan. Perubahan yang terjadi tentunya merupakan perubahan kearah yang lebih baik. Belajar juga merupakan suatu proses timbulnya atau berubanhya tingkah laku melalui latihan (menurut psikolog kognitif).

J.S Bruner dalam Simanjuntak (2004: 228) mengatakan bahwa,"Langkah yang baik dalam belajar Bahasa Indonesia adalah dengan melakukan penyusunan prestasi karena langkah permulaan belajar konsep, pengertian akan lebih melekat bila kegiatan-kegiatan yang menunjukkan model konsep yang dilakukan oleh siswa sendiri dan antara pelajaran yang lalu dengan yang sedang dipelajari harus ada kaitannya”. Secara umum kesulitan yang dihadapi siswa bermacam-macam, adapun kesulitan belajar menurut Djamarah (2006:200-201) dikelompokkan menjadi 4 macam yaitu :

1. Dilihat dari segi kesulitan belajar

a) Ada yang berat

b) Ada yang ringan

2. Dilhat dari mata pelajaran yang dipelajari

a) Ada yang sebagian mata pelajaran

b) Ada yang sifatnya sementara

3. Dilhat dari sifat kesulitannya

a) Ada yang sifatnya menetap

b) Ada yang sifatnya sementara

4. Dilihat dari segi faktor penyebabnya

a) Ada yang karena faktor intelegensi

b) Ada yang karena faktornya non intelegensi.

Kesulitan belajar dilihat dari jenis kesulitan belajar ada yang berat dan ada yang ringan. Setiap siswa mempunyai kadar kesulitan tertentu, hal ini merupakan tugas guru sebagai pendidik dan pengajar untuk mencari solusi agar kesulitan siswa dalam belajar dapat diatasi. Bila kesulitan belajar siswa dilihat dari mata pelajaran yang dipelajarinya, maka dalam mata pelajaran Bahasa Indonesia siswa mengalami kesulitan, hal ini dikarenakan mata pelajaran Bahasa Indonesia merupakan pelajaran yang dirasa sulit bagi siswa. Kesulitan belajar dilihat dari sifat kesulitan antara siswa yang satu dengan siswa yang lainnya (Simanjuntak, 2004: 68). Berikut ini, pemaparan kesulitan dalam pembelajaran Bahasa Indonesia :

\section{Kesulitan Menyimak}

Keterampilan menyimak adalah suatu bentuk keterampilan berbahasa yang bersifat reseptif. Pada waktu proses pembelajaran, keterampilan ini jelas mendominasi aktifitas siswa dibandingkan dengan keterampilan lainnya, termasuk keterampilan berbicara (Iskandarwassid \& Suhendar 2011: 
227). Shihabuddin berpendapat menyimak adalah suatu proses kegiatan mendengarkan lambanglambang lisan dengan penuh perhatian, pemahaman, apresiasi, serta interprestasi untuk memperoleh informasi, merangkap isi serta memahami makna komunikasi yang disampaikan oleh pembicara melalui ujaran atau bahasa lisan (2009: 161). Sejalan dengan hal tersebut, Saddhono (2012: 4) mengatakan bahwa kemampuan menyimak adalah kemampuan berbahasa pertama yang dimiliki oleh manusia dalam pemerolehan bahasa. Oleh karena itu, kemampuan menyimak merupakan modal awal seseorang dalam hal untuk berkomunikasi. Berdasarkan pemaparan di atas, peneliti dapat menarik kesimpulan bahwa salah satu faktor terpenting keberhasilan pembelajaran Bahasa Indonesia di kelas adalah kemampuan siswa dalam proses menyimak informasi yang diberikan guru pada saat pembelajaran dilakukan.

Kesulitan pembelajaran keterampilan menyimak akan berdampak negatif langsung kepada beberapa faktor, antara lain:

1. Menyimak adalah salah satu bentuk keterampilan yang bersifat reseptif. Keterampilan ini langsung berhubungan dengan dua keterampilan produktif baik itu menulis atau berbicara. Oleh karena itu, apabila siswa mengalami kesulitan dalam pembelajaran menyimak, siswa tersebut akan mengalami hambatan dalam pembelajaran keterampilan menulis dan berbicara.

2. Siswa kurang maksimal mendapatkan informasi dan materi yang disampaikan oleh guru secara lisan.

3. Prestasi siswa akan menurun.

4. Siswa menjadi kurang percaya diri dan kurang bisa bersosialisasi dengan teman-temannya.

5. Bila kasus ini tidak segera mendapatkan tindak lanjut akan menggangu perkembangan kecerdasan siswi.

\section{Kesulitan Berbicara}

Selama ini siswa sulit untuk berbicara di depan umum karena rasa kurang percaya diri siswa untuk berekspresi. Rasa kecemasan siswa terhadap penampilannya dalam berbicara membuat mereka enggan untuk melakukannya. Rasa kecemasan akan kesalahan berbahasa seperti penggunaan tata bahasa, pemilihan kosakata, pelafalan, tekanan atau intonasi dapat menghalangi kemampuan siswa untuk berbicara, sehingga siswa tidak dapat menunjukkan kemampuan berbicaranya dengan maksimal. Permasalahan yang sangat fatal adalah adanya pengaruh penggunaan bahasa ibu, hal tersebut menyebabkan siswa mengalami kesulitan untuk berbicara bahasa Indonesia dengan baik dan benar. Secara bersamaan, muncul permasalahan lain yang dapat menghambat kemampuan siswa dalam berbicara, yaitu kesalahan konsep dalam pembelajaran bahasa Indonesia. Dengan adanya permasalahan tersebut menyebabkan siswa tidak dapat berlatih untuk meningkatkan kemampuan berbicara mereka. Hal ini juga akan berdampak negatif terhadap kepribadian siswa. Siswa tidak mampu menyampaikan pikiran dan tanggapan mereka terhadap suatu objek. Ini menyebabkan kemampuan berpikir siswa tidak dapat mengalir dalam menuangkan ide-ide kreatif mereka, karena pada hakikatnya keterampilan berpikir kreatif pun hanya dapat dikembangkan dengan latihan-latihan yang rutin.

\section{Kesulitan Membaca}

Menurut Tarigan (2008:7) membaca adalah suatu proses yang dilakukan serta dipergunakan oleh pembaca untuk memperoleh pesan, yang hendak disampaikan oleh penulis melalui media katakata/bahasa tulis. Tarigan (2008: 7) berpendapat bahwa membaca adalah suatu proses penyandian kembali dan pembacaan sandi. Aspek pembacaan sandi adalah menghubungkan kata-kata tulis dengan makna bahasa lisan yang mencakup pengubahan tulisan/cetakan menjadi bunyi yang bermakna. Menurut Rahim (2008: 2) membaca permulaan adalah kegiatan membaca yang dimulai sejak anak memasuki pendidikan formal, dikatakan sebagai permulaan karena pada tahap ini merupakan tahap peralihan dari lingkungan rumah ke lingkungan sekolah.

Siswa yang mengalami kesulitan belajar membaca diidentifikasi mengalami kesulitan belajar membaca huruf, kata atau kalimat yang bukan diakibatkan oleh kasus-kasus utama seperti terbelakang mental, rendahnya visual dan pendengaran, kelainan gerak serta gangguan emosional. Kesulitan membaca itu berkenaan dengan (1) kebiasaan membaca, (2) kekeliruan mengenal kata, (3) kekeliruan pemahaman, dan (4) gejala serbaneka (Mercer dalam Abdurrahman, 2003). 
Karakteristik kesulitan belajar membaca yang berkaitan dengan kebiasaan membaca yang tidak wajar berupa gerakan yang penuh ketegangan, seperti mengernyitkan kening, gelisah, irama suara meninggi, atau menggigit bibir. Di samping itu, juga memperlihatkan perilaku menolak untuk membaca, menangis, atau mencoba melawan guru. Karakteristik lainnya berupa pengulangan atau ada baris yang terlompati tidak terbaca, gerakan kepala ke kiri atau ke kanan, kadang-kadang meletakkan kepala pada buku, dan jarak membaca yang kurang dari 37,5 cm (Abdurrahman, 2003).

\section{Kesulitan Menulis}

Menulis merupakan kegiatan penting dalam proses pembelajaran setelah membaca, seseorang menulis pasti mempunyai suatu tujuan yang ingin disampaikan. Menulis adalah menurunkan atau melukiskan lambang-lambang grafik yang menggambarkan suatu bahasa yang dipahami oleh seseorang, sehingga orang-orang lain dapat membaca lambang-lambang grafik tersebut kalau mereka memahami bahasa dan gambaran grafik itu (Tarigan 2013 : 22). Latihan menulis juga sangat penting untuk membantu kebiasaan anak dalam belajar menulis. Hartati (2006: 165) menyatakan ada beberapa bentuk latihan menulis permulaan yang dapat dilakukan antara lain:

1. Latihan memegang pensil dan duduk untuk menulis dengan sikap dan posisi yang benar.

2. Latihan mengeblat, yaitu menirukan atau menebalkan suatu tulisan dengan menindas tulisan yang sudah ada.

3. Latihan menghubung-hubungkan tanda titik yang membentuk tulisan dapat dilakukan pada buku-buku yang secara khusus menyajikan latihan semacam ini.

4. Latihan menatap bentuk tulisan.

5. Latihan menyalin, baik dari buku pelajaran maupun dari tulisan guru pada papan tulis

6. Latihan menulis halus/indah.

7. Latihan dikte/imla.

8. Latihan melengkapi tulisan (melengkapi huruf, suku kata, dan kata) yang secara sengaja dihilangkan.

9. Menuliskan nama benda yang terdapat dalam gambar.

10. Mengarang sederhana dengan bantuan gambar.

\section{Faktor-faktor Penyebab Kesulitan Siswa dalam Menguasai Bahasa Indonesia}

Berikut faktor-faktor penyebab kesulitan belajar seperti yang telah dikemukakan oleh Slameto (2005:57-59).

1. Faktor internal

Faktor internal adalah faktor yang bersumber dari dalam diri individu itu sendiri dalam mencapai tujuan belajar. Faktor internal ini sangat besar pengaruhnya tetapi tidak disadari karena dianggap suatu hal yang biasa, sebenarnya faktor ini dapat dibagi dua bagian yaitu faktor fisiologis dan faktor psikologis.

a) Faktor fisiologis

Faktor fisiologis adalah faktor yang bersumber dari dalam individu yang erat hubungannya dengan masalah kejasmanian terutama tentang fungsi alat panca indera, karena panca indera ini merupakan pintu masuk perangsang dari luar kedalam individu yang dioalah oleh untuk diterima atau tidak pengaruh tersebut.

b) Faktor psikologis

Faktor-faktor psikologis yang mempengaruhi proses belajar siswa antara lain: 1) Kecerdasan (intelegensi) 2) Bakat 3) Minat 4) Motivasi 5) Cara belajar.

2. Faktor eksternal

Faktor eksternal adalah faktor yang berasal dari luar diri siswa yang dapat mempengaruhi prestasi siswa. Faktor eksternal yang dapat mempengaruhi prestasi seseorang ada tiga yaitu faktor keluarga, faktor sekolah, dan faktor masyarakat. 


\section{CONCLUSION AND SUGGESTION}

Setelah dilakukan kajian dan pembahasan mengenai kesulitan belajar siswa pada pembelajaran bahasa Indonesia di kelas V SDN 12 Singkawang, maka peneliti menarik kesimpulan yaitu kesulitan belajar yang dihadapi siswa pada pembelajaran Bahasa Indonesia yakni meliputi : kesulitan siswa dalam menyimak, kesulitan berbicara, kesulitan membaca, dan kesulitan dalam menulis. Hal tersebut disebabkan oleh beberapa faktor yang menyebabkan siswa belum mampu untuk mengikuti pembelajaran bahasa Indonesia dengan baik dan belum mampu untuk mencapai tujuan-tujuan pembelajaran yang diharapkan oleh guru.

Berdasarkan kesimpulan di atas, maka peneliti menyarankan, Bagi Siswa SDN 12 Singkawang, hendaknya memiliki semangat dan motivasi belajar yang lebih tinggi terhadap mata pelajaran bahasa Indonesia. Setelah itu, disarankan kepada kepala sekolah untuk menyediakan sarana dan prasarana yang lebih memadai bagi guru maupun siswa dalam kegiatan pembelajaran bahasa Indonesia, sehingga proses pembelajaran lebih optimal serta dapat mengembangkan model-model pembelajaran yang inovatif dan menggunakan media yang menunjang siswa untuk lebih mudah dalam memahami pembelajaran bahasa Indonesia. Selain itu, guru perlu membangkitkan semangat dan motivasi belajar siswa terutama dalam pembelajaran Bahasa Indonesia, dan disarankan kepada peneliti lainnya untuk melakukan kajian lebih mendalam tentang kesulitan belajar bahasa Indonesia yang dialami siswa sekolah dasar.

\section{REFERENCES}

Abdurrahman, M. (2003). Pendidikan bagi anak berkesulitan belajar. Jakarta: Depdikbud \& Rineka Cipta.

Abdurrahman, M. (2003). Pendidikan bagi anak berkesulitan belajar. Jakarta: Depdikbud \& Rineka Cipta.

Anzar, Safni Febri dan Mardhatillah. 2017. Analisis Kesulitan Belajar Siswa Pada Pembelajaran Bahasa Indonesia Di Kelas V Sd Negeri 20 Meulaboh Kabupaten Aceh Barat Tahun Ajaran 2015/2016. Jurnal Bina Gogik. 4(1).

Depdiknas, 2007. Standar Proses untuk Satuan Pendidikan Dasar dan Menengah. Pusat Pembukuan Departemen Pendidikan Nasional. Jakarta.

Djamarah, S.B. 2006. Proses Belajar Mengajar. Jakarta: Bumi Aksara.

Hartati, Tatat, dkk. 2006. Pendidikan Bahasa dan Sastra Indonesia di Kelas Rendah. Bandung: Upi Press.

Irham, Muammad dan Novan Ardi Wiyani. 2014. Psikologi Pendidikan. Jogjakarta: Ar-Ruzz Media.

Iskandarwassid \& Sunendar.D. 2011. Strategi Pembelajaran Bahasa. Bandung: Rosda.

Rahim, F. 2008. Pengajaran Membaca di Sekolah Dasar. Jakarta: Bumi Aksara.

Saddhono. 2012. Meningkatkan keterampilan berbahasa indonesia. Bandung: Karya Putra Darwanti.

Shihabuddin. 2009. Modul evaluasi pengajaran bahasa indonesia. Bandung: SPS UPI.

Simanjuntak, L. 2004. Metodologi Mengajar. Jilid I. Jakarta: Rineka Cipta.

Slameto, 2005. Belajar dan Faktor-faktor Yang Mempengaruhinya. Jakarta: PT. Rineka Cipta.

Tarigan, Henry Guntur. 2008. Membaca Sebagai Keterampilan Berbahasa. Bandung: Angkasa.

Tarigan, Henry Guntur. 2013. Menulis Sebagai Keterampilan Berbahasa. Bandung: Angkasa. Tarigan, Henry Guntur. 2013. Menulis Sebagai Keterampilan Berbahasa. Bandung: Angkasa.

Tristiantari, Ni Ketut Desia, dkk. Pengaruh Implementasi Model Pembelajaran Kooperatif Tipe TPS Terhadap Kemampuan Berbicara dan Keterampilan Berpikir Kreatif Pada 
Siswa Kelas V SD Negeri Gugus III Kecamatan Seririt. Journal Program Pascasarjana Universitas Pendidikan Ganesha, Volume 3 Tahun 2013.

Tristiantari, Ni Ketut Desia, dkk. Pengaruh Implementasi Model Pembelajaran Kooperatif Tipe TPS Terhadap Kemampuan Berbicara dan Keterampilan Berpikir Kreatif Pada Siswa Kelas V SD Negeri Gugus III Kecamatan Seririt. Journal Program Pascasarjana Universitas Pendidikan Ganesha, Volume 3 Tahun 2013. 